\title{
Mediation in Niger Delta Resource Conflict: Assessing the Determinant of a Successful Process
}

\author{
Ola Abegunde Ph.D \\ Is on post-doctoral fellowship with the Department of Politics, Peace Studies \& International Relations, North \\ West University, Mafikeng, South Africa.
}

\begin{abstract}
The Niger Delta region in Nigeria is richly endowed with abundant crude oil resources that place the nation as the seventh largest producer of oil in the world. The oil wealth enriches Nigeria as a country but it has not alleviated the challenges of poverty and social development in the oil producing areas of the Niger Delta. Owing to this, the region has been redden by youth restiveness despite several interventions initiated by organizations, government and international community that have not yielded any positive result since the conflict has escalated and received international coverage in the 1990s. The aim of this study is to first examine the causes of the protracted resource conflict in the region; it will do a review of the initiatives so far taken and the reasons for their failure. Also, the study will investigate the likely determinants of a successful process of mediation that can restore peaceful co-existence to the region. The paper is of the opinion that the protracted violent conflict in the region is a product of the lopsidedness of Nigeria federalism. Hence, the study submits that, to have peace in the region, there is need for true federalism in such that the people in the region will be meaningfully engaged in any initiative to resolve the violent conflict in the region.
\end{abstract}

Keywords: Nigeria, Niger Delta, Federalism, Resource conflict and violent conflict

\section{Background}

Niger Delta region wasknown as the 'oil rivers'during the colonial era until 1893 when its borders were expanded and renamed as the Niger Coast Protectorate. Hence, it was once a major producer of palm oil in the country before the discovery of crude oil in the region. The major occupation of the people in the region was fishing and farming, especially oil production which earn them the name Oil River Protectorate. Before the advent of commercial oil production in the Niger Delta about fifty six years ago (in1958), the region was essentially a pristine environment which supported substantial subsistence resources for the mostly sedentary populations. These included among other things, medicinal herbs and barks, fish and shrimp, crabs and clams, wood for energy and shelter, as well as a stable soil for farming and habitat for exotic wildlife. There was the Delta elephant, the white crested monkey, the river hippopotamus, as well as a colorful array of exotic birds, crocodiles, turtles and alligators. The region also accounted for a large percentage of Nigeria's commercial fisheries industry (Afinotan and Ojakorotu, 2009: 194). The Niger Delta region as now been officially defined by the Nigerian government to cover an area of 70,000 kilometer square that make up 7.5\% of Nigeria's land mass. Historically, the Niger Delta region consists of the present Bayelsa, Delta and River states, but in 2000 the Chief OlusegunObasanjo regime include six other oil producing states to the region. The states are: Abia, Akwa-Ibom, Cross River, Edo, Imo and Ondo states.

The Niger Delta that produces the bulk of Nigeria's oil wealth and the largest producer of oil in Africa remains one of the least developed parts of the country. The region is reputed to be the third largest wetland in the world, which sustains a complex biodiversity, otherwise alternative to tourists, explorers-adventures, traders, businessmen/ women, academicians and a variety of researchers (Otite, 2009). Therefore,oil-bearing communities of Niger Delta have remained grossly socio-economically dependent, underdeveloped and persistently disempowered, politically marginalized and psychologically alienated. This paradoxical development has prompted a protracted conflict for over five decades without meaningful and sustainable solution yet on sight. The conflict has manifestedin violence and militarization of the people in the region, resulting to militant violent attacks on the multinational corporations, theft of oil by syndicates and destruction of oil installations on one hand, intra and inter-ethnic conflict, community and militia conflict, and militants and government agents conflicts on the other hand.

The discovery and exploitation of oil in the Niger Delta has become a curse rather than blessing to the people in the region in that,individuals and communities that have been peacefully co-existing suddenly began to suspect one another and further engage in violent conflict because of the oil wealth in the region. This is due to the failure of government at all levels (federal, state and local) to manage the protracted crisis in the region, this development has attracted global attention and subsequently placed theregion on the world map. Therefore, this has portrayed the country as a weak state, if not even a failed state. 
The Niger Delta crises is a grave matter that deserves serious and urgent attention in the area of policy formulation and policy implementation by a true national and courageous leadership that is sincerely interested in the peace and development of Niger Delta, and by extension Nigeria. The Niger Delta people have endured a long pain of economic, political, and social injustice over the oil resource in their community (oil-bearing communities) which they should 'ordinarily be getting royalty from the multinational corporations and subsequently paying tax to the federal government, based on a true federal composition of the country'.

Contrary to this, environmental damage from oil exploration as a result of oil spillage, unemployment, poverty, violation of fundamental human rights, destruction of farm land and many more are all that the Niger Delta people could get in return for God's kindness that makes them oil-bearing communities.

Bearing in mind the overwhelming wealth of scholars research and literatures that have been compiled on the activities relating to Niger Delta crisis, it will be of no advantage to revisit the existing volumes of studies compiled. Rather, the focus of this study is therefore on the causes of the unabated crisis in the Niger Delta region, dimensions of the crisis in the region, initiative so far taken in managing the crises, reasons for their failure and determinants of workable solution to the crisis in the region. This is important because of the need to demilitarize the region, engage them in serious and meaningful discussion and development that will restore their hope and therefore make them embrace peace.

\section{Origin And A Review Of The Causes Of Disharmony In Niger Delta}

Conflict is an inevitable and a necessary phenomenon in any human society that strives for development. Therefore, Niger Delta is not immune of conflict even before the discovery of oil in commercial quantity. In the region, like every other region in the country, there have been conflicts over land space for agriculture which was their main occupation before the discovery of oil, chieftaincy tittle, and cultural interest among others. The violence between the Itsekiri and Ijaw appears to be the most prominent and can be traced to colonial conquests, integration, trade relations and the institutionalization of Itsekiri dominance through the paramount status acquired by the Itsekiri monarch (Ukiwo, cited by Ibaba and Ikelegbe, 2010: 232). In the submission of Otite (2009) "the area is characterized by ethnic pluralism as inhabited by Andoni, Bekwara, Bini, Efik, EgbemaEkoi, Ibiobio, Igbo, Ijaw, Isoko, Itsekiri, Ogoni, Urhobo, and several others". He further argues that, naturally, there is phenomenon of ethnic conflicts as different cultural interest groups engages in competition for access to limited resources and contested territorial claims. Many of such conflictsspecifically involved the Ijaw, Itsekiri and Urhobo, occurred and were resolved or transformed through dialogue and government intervention towards peaceful co-existence in the region.

The Niger Delta region is abundantly endowed with petrol which abounds in the creeks of the terrain, across to the ocean. However, due to the peculiar historical trajectory, any reference to the Niger Delta has become synonymous with the abundance of valuable oil resources on the one hand and the political, economic, and ecological destruction which has resulted from exploration and taxation of the resource, on the other hand (Ojakorotu, 2008). The protracted conflict in Niger Delta arose in the early 1990s due to tension between the foreign oil corporations and a member of the Niger Delta's minority ethnic groups on one hand and the government on the other hand, who felt they were being exploited, particularly the Ogoni as well as the Ijaw. Since then, ethnic and political unrest have continued in the region despite the adaptation to democratic system of government since 1999. The militancy in the Niger Delta is therefore occasioned by the endemic poverty of the locals, flagrant environmental degradation and destruction of livelihood sources by multinational oil corporations (MNOCs), marginalization and inequitable distribution of revenue, repression and human right abuse (Sampson, 2009: 31)

Shell Petroleum Development Company (SPDC), one of the MNOCs acknowledged environmental problem in the region. According to SPDC, "the environmental problems of the area are grouped into two broad categories: oil related and non-oil related environmental problems" SPDC explains further that, the most common environmental problems related to the oil industry are: oil spills, gas flaring, dredging of canals and land for the construction of facilities. Meanwhile, the non-oil related environmental challenges include: Coastal/ river back erosion, flooding, spread of exotic species, agricultural land degradation, fishing depletion, inadequate sanitary and waste management, and emission discharges from industries (www.shellnigeria.com).

The recurring crisis in the Niger Delta region is the product of the deep-seated sense of neglect and marginalization by the government and oil companies in supporting critical human development and provision of basic social amenities (Aboribo and Umukoro, 2008).

Ebienfa (2011: 637), submits that, the causes of Niger Delta disharmony can be divided into remote and immediate: the remote causes include environmental degradation, marginalization and unemployment in the region, the existence of obnoxious laws such as the petroleum act of 1969 and the Land Use Act of 1978, and the killing of Ken Saro-wiwa. On the other hand the immediate causes include the militarization of the Niger Delta by the Nigerian state, the 'Youth Earnestly Ask for Abacha' programme, the Kaiama Declaration, bunkering by Niger Delta youths, and the mobilization of youths as political thugs during the 1999 elections. 
The case of Niger Delta is just like the case of individuals or group of people confronted with challenges like neglect, marginalization, oppression, unemployment and poverty.Despite producing the major wealth as the sources of the nation's revenue, however, the 'wealth' oil has been more of curse than blessing to the people who have been at the receiving end of its exploration since 1958. There is tendency that they will device an alternative means of rescuing themselves from the conspiracy and alliance of a tyrannical and oppressive authority. In a nutshell, oil and its management is the primary factor that gave birth to the various factors discussed by scholars as the causes of disharmony in the Niger Delta region.

\section{Dimensions Of Niger Delta Conflict}

The Niger Delta violent conflict started after the declaration of Niger Delta republic in 1966 by Jasper Isaac AdakaBoro, an Ijaw nationalist who led an armed campaign for greater Niger Delta autonomy, resource control and self-determination for the inhabitant of the region. While justifying his action, Boro argues that "most of the youths were so frustrated with the general neglect that they were ready for any action led by an outstanding leader to gain liberty... we were clenched in tyrannical chains and led through a dark alley of perpetual political and social deprivation" (Nairaland Forum, 2012:1). This conviction led him with the assistance of Samuel Owonaru and comrade Nottingham Private to recruiting of young men to their cause under the umbrella of Niger Delta Volunteer Force (NDVF) which eventually led to establishment of a military camp at Taylor Creek. Their recruits numbering 150 men were given training in the use of firearms and explosives in the creeks and bushes (Nairaland Forum, 2012:2).In a related view, Sampson (2009: 31), argues that the militancy in the Niger Delta is not a new phenomenon, "as early as 1966, Isaac Jasper AdakaBoro, a former police officer from the Delta, led a rebellion against the Nigerian state with the aim of achieving liberation for the Niger Delta people.

On 23 February 1966, NDVF under the leadership of Boro, Onwonaru and Privates attacked a police station in Yenagoa,raided the armoury and kidnapped some officers in the police station; they blew pipelines, engaged the police in a gunfight and announced the independent of Niger Delta republic, but in a swift response their action was suppressed by the federal troop, Boro was arrested and subsequently put on trial on a 9 count charge of treason by the federal government. The deed had been done by instilling into the mind of Niger Delta people the consciousness that the region was being marginalized,oppressed, victimized, anddeprived of the control of their natural resources, before the suppression of NDVF. Hence, this arise the need for their struggle and agitation for self-determination.

The Niger Delta crisis was internationalized by Ken Saro-Wiwa through his publicities and the issue of the murder of Ogoni four that led to the hanging of Ogoni nine and execution of Ken Saro-Wiwa in October 1995.Saro-Wiwa not only succeeded in directing the attention of the international community to the plight of the people in the Niger Delta but also - through his advocacy - paved the way for robust international / civil society engagement with the issues at the core of the crisis in the region (Ojakorotu, 2009:3). He argues further that his submitted fact has been illustrated by theintervention of organizations such as Amnesty International, GreenPeace Movement, Rainforest Action Group, the Commonwealth ofNations and the United Nations interventions in the Niger Delta crisis.

The 1998 Kaiama Declaration after the resolution of a meeting of the Ijaw Youths Conference (IYC) held in Kaiama,Bayelsa State, the resolution order all the oil producingcompanies to vacate the region latest December 1998. This was an attempt by the Ijaw Youth Council (IYC) to reassert their rights over their land and resources. The Kaiama Declaration was sign by several thousands of Ijaw youths and marked the starting point of every radical demands and subsequent military operations against youth protests that followed (Ibaba and Ikelegbe, 2010: 226)

In 2003 there was a rivalry clash between the gangs and cults loyal to Asari-Dokubo of the Niger Delta People's Volunteer Force (NDPVF), Niger Delta Peoples Salvation Front (NDPSF) and Ateke Tom of the Niger Delta Vigilante Group (NDVG).

The involvement of Movement for Emancipation of Niger Delta (MEND), added a new dimension which include, illegal bunkering, cultism, militancy, sea piracy, hijacking of vessels, hostage taking and kidnapping. In a similar view, Ojakorotu (2009:3) remarks that "the crisis has taken a new turn with increasing criminalization of the conflict, leading to questions as to why the problem is seemingly spiraling out of control".

The crisis has created a weird booming business of hostage taking for money and storming of banks (Dike, 2001:3), in a related submission, Isele (22 Feb 2006), "hostage taking has become a lucrative business providing a means of spending money without proper accountability".

This can as well be summarized thus: between 1950 and 1965 there was civil agitation for special development attention; militant insurgence of AdakaBoro in 23 February to 6 March 1966. In 1970 to 1982 there were agitations by the oil-bearing communities against transnational corporations, in another related development; in 1983 to 1990 the agitations of oil-bearing communities degenerated to violent conflict over non-payment of adequate compensation for damages and for development projects. After the violent conflict, in 
1990 through 1996 there were peaceful demonstrations, but when the demonstrations were not yielding the expected results there were formation of ethnic militants between 1997 and 2009 that engaged both the government and the oil corporation in violent confrontations.

\section{Initiatives So Far Taken In Resolving The Crises}

The protracted Niger Delta violent conflict that started in the 1950s has attracted a lot of recommendations and suggestions for its resolution, but for varied reasons none has worked to achieve peace in the region. The first initiative was the setting up of Sir Henry Willink's Commission in 1957 in response to the concern of ethnic minorities over their perceived slim chances of survival in the Nigeria enterprises, by the colonial administration. In 1959, there was establishment of Niger Delta Development Board Authority (NDDB) through supplementary Federal Government Gazette no 56 vol. 46 of September 1959. In 1979, the Niger Delta Basin Authority was established. There was a creation of special fund for the oil producing areas, by the revenue Act of 1981. In 1989, there was inauguration of Presidential Task Force for the development of oil producing areas. Subsequently in 1992, Oil Mineral Producing Areas Development Committee (OMPADEC) was established.

In year 2000, Niger Delta Development Commission (NDDC) was created. In 2002, there was General Ogomudia Committee. The Niger Delta Peace and Conflict Resolution was instituted in 2007, this was followed by Technical Committee on Niger Delta in 2008. After a careful assessment of the performance of the various institutions established by government to develop Niger Delta region, it was discoveredthat they have failed in their responsibilities and purpose of their establishment. Based in this, there was establishment of Ministry of Niger Delta in 2008 to replace the earlier established institutions. In an effort to resolve the Niger Delta crisis president Yar'Adua in his inaugural address submits that, "the crisis in the Niger Delta commands our attention and it is a matter of strategic importance to our country. I will use every resource available to me to address this crisis in a spirit of fairness, justice and cooperation". He further asserts that we have a good starting point because our predecessor has already launched a master plan that can serve as a basis for a comprehensive examination of all issues. We will involve all stakeholders in working out a solution. As part of these efforts, we will move quickly to ensure the security of lives and property and investment. In the meantime, I appeal to all aggrieved communities to suspend all forms of violence. Let us allow the impending dialogue to take place ina conducive atmosphere. We are all in this together, and we will find a way to achieve peace and justice (Yar'Adua, 2007).

On 8 September 2008, a technical committee headed by LedumMitee was inaugurated to "distill the various reports, suggestions and recommendations on the Niger Delta from the Willinks Commission Report of 1958 to the present and give a summary of the recommendations necessary for government action" (Otite and Umukoro, 2011: 218). The Amnesty Programme is one of the recommendations of the 2008 Mittee Committee report which was based on the need to achieve sustainable development, peace, human and environmental security in the region.

\section{Reasons For The Failure Of Past Initiatives}

It is unfortunate that despite the series of committees, recommendations and institutions established, the problems of Niger Delta region still persist because of the following: insincerity on the part of all the stakeholders. It is unfortunate that the stakeholders are not giving the crises in the Niger Delta region the deserve attention in other to bring the crisis to an end because of their inherent benefit. The militants are benefiting financially through bunkering, hostage taking among other activities. The multinational corporations are maximizing their gains when they are not performing their social responsibilities to their host communities through payment of royalty and provision of basic amenities in substitute for destroyed natural habitat of the region. While on the other hand, the major source of government revenue is from the region, because of the greed on the part of government to maintain the statoscope in the country, the needed support were not always given to the various established institution for the region to make success of their assignments.

Employment is another crucial factor that is hindering the success of the past initiatives. No matter the good intention of the government and other stakeholders in resolving the Niger Delta crisis, as long as the inhabitants, the young able men are not gainfully engaged they will be easily penetrable and become useful instruments for the militants that will provide themtheir daily meal for survival.

Another reason for failure of past initiatives is that, the people in the oil-bearing communities are not always adequately and sincerely represented either in the institutions established or at the level of committees that do formulate policies for the resolution of the crisis in the region. At another level, the community people that are directly affected are not always well represented in the implementation of policies meant for crisis resolution in the region, rather people that do not know the happenings and the history of the region are mostly appointed as institution or committee head for policy implementation. 
Poor leadership is another perceived reason for the failure of past solutions, in that, the attitude of the political leadership in Nigeria since the agitations of the Niger Delta, it seems have not shown enough commitment to the resolution of the crisis. Probably they are not directly from the region, even those in positions of authority that are from the region are not passionately committed to the resolution of the crisis simply because they mostly leave in the urban centers where they are comfortable and not directly affected.

\section{Determinants Of Workable Solution}

As it has been noted above, conflict is an unavoidable phenomenon in any human society that is striving for development. Hence, there are solutions to every crisis in as much as every party involved are ready to compromise their rigid stand for peaceful resolution. In the case of Niger Delta, when the people that are directly affected are involved in the process and implementation of resolution, there is high degree of likelihood of success of such, because they will be directly involve in issues that affects them, which they have better information and better understanding that every other person claiming to be working to end the conflict. This approach is referred to as participatory by (Kepner and Likubo, 1996: 12-15), when they argue that conflict management is a collaborative approach to problem solving and a decision making that places an equal priority on therelationship with the other parties and on a mutually satisfying outcome. They further submit that, the strategy of the 'problem-solving' conflict management style includebuilding trust, communicating face-to-face, gathering information, dialoguing,negotiating, valuing diversity, team building, having focus group discussions,searching for alternatives and seeking 'win-win' solutions.

Employment and employment opportunities is another strong factor that can allow for peaceful resolution of the crisis in the Niger Delta region. When the inhabitants of the region are gainfully employed, have opportunities for better job, and have hope for better future, the youths will ceased to be instrument of violent conflict in the hands of militant commanders.

There is need to orientate the Niger Delta people on the correlation between peace and development, and awaken the consciousness and willingness for genuine dialogue that will lead to compromise among the stakeholders, take and embrace new stand that will bring back the lost peaceful co-existence of the people of the region and subsequently allow for all round development of the region.

In addition to the above, the Niger Delta people should be encouragedto be shareholders in the oil producing multinational corporations and supported with parliamentary legislation that will allow the people in the region to have legitimate right to a specified percentage of the entire corporations' share. It is confidence that this will change their perception in that if they are not benefiting enough from the multinational corporation, and their approach to issues will be less militaristic and violent because they should have been co-owners of the industries. Therefore, no reasonable individual will want to destroy or encourage others to destroy his/ her investment, rather peaceful resolution will always be sought for any agitation.

\section{Recommendation And Conclusion}

Owing to the militarization and unabated violent conflict in the region, there should be a renewed and more peaceful approach to addressing both the remote and immediate causes of the crisis. All that is required to solve the Niger Delta crisis is a genuine and meaningful dialogue with the real people who are directly affected in the region by visiting the Ogoni Bill of Right and Kaiama Declaration as lasting solution to the violent conflict in the region (Ahmad, 2009).

Government should initiate programmes of demobilization, rehabilitation and re-integration of militants in such that will make them self-dependent. There must be a review of the contentious and obnoxious laws (Land Use Decree and Petroleum Act)that seems to inhibit the participation of host communities in the enterprises of the oil and gas industry.

There is urgent need to practice true Federalism that will allow for self-determination that will include resource control by all the federating units, in a manner similar to the Nigerian's first republic which allowed healthy competitive development among the regions.

In conclusion, without genuine commitment of the stakeholders for resolutions that will bring about peaceful co-existence and development of the inhabitants of Niger Delta, no matter how beautifully packaged any programme for conflict resolution in the region might be, it will always not meet its expectations. Therefore, this study suggests that the government should allow and encourage collaborative model of conflict resolution that will involve all the stakeholders to proffer a lasting and enduring solution to the Niger Delta crisis. 


\section{References}

[1]. Aboribo, R.O. and Umukoro, N. (2008): "Conflict of Globalization and the Globalization of Niger Delta conflict" in Nigerian Sociological Review, Vol. 8.

[2]. Afinotan, L.A. and Ojakorotu, V. (2009): "The Niger Delta Crisis: Issues, Challenges and Prospects" in African Journal of Political Science and International Relations Vol. 3. No 5 http://www.academicjournals.org/AJPSIR (accessed 14/11/2012).

[3]. Ahmad, I.A.R. (2009): "Ogoni: Bill of Right as a Solution to Niger Delta Conflict" in Unrepresented Nations and Peoples Organization. http://www.unpo.org/article/9845 (accessed 15/11/2012).

[4]. Dike, V.E. (2001): Niger Delta Crisis and the Nigeria Economy. http:/www.mhtml:file://H:LNIGERDELTAFILE\niger.org (accessed, 12/11/2012)

[5]. Ebienfa, K.I. (2011):“Militancy in the Niger Delta and the Emergent Categories" in Review of African Political Economy, Vol.38. 130

[6]. Ibaba, I.S. and Ikelegbe, A. (2010): "Militias, Pirates and Oil in the Niger Delta" in Okumu, W. and Ikelegbe, A (eds) Militias, Rebels and Islamist Militants Human Insecurity and State Crises in Africa. South Africa; Institute of Security Studies.

[7]. Isele, P. (2006): "Militants Blow Up Another Oil Boat" in The Punch. Lagos; Punch Nigeria Limited

[8]. Kepner, C.H and Likubo, H. (1996): Managing Beyond the Ordinary. New York; AMACOM

[9]. Nairaland Forum (2012): Isaac AdakaBoro and Niger Delta Militancy - Politics - Nairaland. mhtml:file://H:INIGERDELTAFILE (accessed, 01/11/2012

[10]. Nnenyelike, N. (2009): Why Niger Delta Crisis Persists. http://www.indigenouspostal.com/news/ (accessed 14/11/2012)

[11]. Ojakorotu, V. (2009): "Introduction" in Ojakorotu, V (ed), Fresh Dimentions on the Niger Delta Crisis of Nigeria: Part of the Conflict and Development Series. South Africa; JAPSS Press, Inc.

[12]. Ojakorotu, V. (2008): "Environmental Activism and the Struggle for Justice by the Non-Governmental Organizations in the Niger Delta of Nigeria". The International Journal of Regional and Local Studies. United Kingdom; Series 2.Vol.4, No2 Autumn.

[13]. Otite, A. and Umukoro, U. (2011): “Amnesty Programme and the Niger Delta: Overview of Disarmament, Democratization, and Reintegration (DDR) Strategy for Sustainable Peace” in African: The Niger Delta Special Issue, Vol.5, No1.

[14]. Otite, O. (2009): “The Complexity Behind Nigeria's Niger Delta Crisis" in http://www.bornblackmag.com/crises-Niger-Delta.html (accessed 04/11/2012)

[15]. Sampson, I.T. (2009): "Niger Delta Militancy and the Challenge of Criminalising Terrorism in Nigeria" in African Security Review Vol 18 No2 June 2009. South Africa; Institute of Security Studies.

[16]. SPDC www.shellnigeria.com (accessed 10/10/2012)

[17]. Yar,Adua,U. (2007): "Let's March into the Age of Restoration" in the full text of Presidental Inaugural Address. allafrica.com/stories/200705300657.html 